\title{
Katsauksia
}

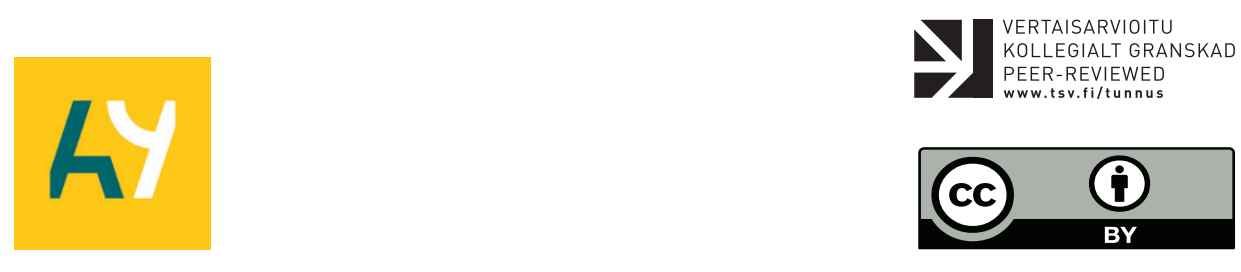

Mikko Karhu

\section{Utopia, utopismi ja paikan tutkimus}

\section{Johdanto}

Esittelen tässä katsauksessa väitöskirjani tutkimusaihepiirin, johon olen perehtynyt aiemmin valmistuneessa lisensiaatintutkimuksessani (Karhu 2016). Se käsitteli kolmea utopia- ja dystopiakirjallisuuden lajityyliin kuuluvaa klassikkoteosta, jotka ovat Thomas Moren Utopia, George Orwellin Vuonna 1984 ja Aldous Huxleyn Uljas uusi maailma. Tutkimuksessa tarkastelin fiktiivisiä klassikkoteoksia maantieteen paikan (place) tutkimusperinnön näkökulmasta saadakseni selville, millaisia paikkoja nämä kaunokirjallisuuden tunnettujen teosten kuvaamat yhteiskunnat ovat. Tutkimukseni aikana tietämykseni ja ymmärrykseni aihepiirini keskeisistä tieteellisistä käsitteistä - utopiasta, utopismista ja paikasta - kehittyivät. Käyn tämän käsitekolmikon läpi tuoden esille niiden keskinäisen yhteyden tavalla, joka palvelee lisensiaatintyöni kehittämistä väitöskirjaksi. Väitöskirjassani painopiste siirtyy aluekehittämiseen kaunokirjallisuuden sijasta. Liitän katsauksella edeltävän opinnäytetyöni kolme keskuskäsitettä aluekehittämiseen jatkotutkimusta varten. En keskity katsauksessa muutoin aluekehittämiseen kuin pohtien yhteenvedossa sitä, millaisiin aluekehittämisen teemoihin aiemman tutkimukseni kolme keskeistä käsitettä liittyvät.

Utopiatutkimus on oma tieteenalansa, joka jaetaan kolmeen tutkimusteemaan ("utopismin kolmet kasvot") (Sargent 2010, 5-7). Kirjallisuuden utopiat (literary utopia) keskittyvät kaunokirjallisuudessa kuvattujen fiktiivisten yhteiskuntien ja paikkojen tutkimukseen. Lisensiaatintutkimukseni on lähimpänä tätä utopiatutkimuksen osa-aluetta. Utopiakäytännöt (utopian practice) tarkoittavat utopiayhteisöjen ja utopiakokeilujen, niin sanottujen "todellisten utopioiden" historian ja merkityksen tutkimusta. Utopian yhteiskuntateoria (utopian social theory) puolestaan tarkastelee utopioiden ja utopismin merkitystä yhteiskunnallisten ilmiöiden kuten politiikan, vallankumousten ja kulttuurien syntymisen taustavoimana. Väitöskirjaksi kehitettävä lisensiaatintyö kallistuu viimeksi mainitun utopiatutkimuksen puoleen.

Utopian, utopismin ja paikan käsitteiden yhteyden perusteellisemmalle tieteelliselle tarkastelulle on tilaa yhteiskuntamaantieteessä, johon utopiatutkimusta ei ole toistaiseksi sovellettu sen potentiaalin arvoisesti. Etenkin siitä hyötyy aluekehittäminen, jota on luonnehdittu (mm. Viinamäki \& Salminen 2008, 23-24; Lundström 2016, 70) sen nykykäsityksen mukaisesti moniselitteiseksi ja toisinaan kaoottiseksi toimintaympäristöksi. Se luo entistä suuremman tarpeen ottaa selvää utopioista ja niiden merkityksestä alueille. Utopioita myös viljellään yhteiskunnallisessa kontekstissa, kuten aluekehittämisessä leväperäisesti.

\section{Utopiat ja niiden keskeiset haasteet}

Utopia tuli sanana tunnetuksi Thomas Moren keskiajalla kirjoittamasta samannimisestä kirjateoksesta. Vuonna 1516 ensimmäisen kerran julkaisemassaan Utopiassa More kertoo 
kuvitteellisesta kaukaisesta saaresta ja sen asukkaista. (Lahtinen 2002, 169-171; Sargent 2010, 10-11.) Moren teos antoi utopialle sen tunnetuimmat merkitykset, jotka ovat sanan ääntämisestä riippuen joko olematon paikka $(\mathrm{ou}=\mathrm{ei}$, topos $=$ paikka) tai onnellinen paikka $(\mathrm{eu}=$ onnellinen, topos $=$ paikka). Tämän teoksen ansiosta utopiaa alettiin käyttää tyypillisessä merkityksessä eli niin hyvänä tai ihanteellisena paikkana, että sellaista ei ole olemassa muutoin kuin kuviteltuna (Claeys \& Sargent 1999, 1-2; Sargent 2010, 10-15).

Moren teos johti utopiakirjallisuudeksi kutsutun kaunokirjallisuuden lajityylin syntyyn. Tätä kirjallisuuden genreä leimaa samankaltaisten fiktiivisten ihanneyhteisöjen kuvaaminen. Utopiakirjallisuuden tunnettuja teoksia kautta aikain ovat muun muassa keskiajan ja uuden ajan alun murroksessa kirjoitettu Francis Baconin Uusi Atlantis, Tommaso Campanellan Aurinkokaupunki sekä H.G. Wellsin jo 1900-luvun puolella julkaistu Moderni Utopia. Utopiakirjallisuus teki utopiasta käsitteenä entistä tunnetumman. (Lahtinen 2002, 169-173; Lakkala 2014, 31-41.)

Moren merkkiteos ei ole ensimmäinen kirjallisuuden kuvaus ihannepaikasta länsimaisessa kulttuurissa, saati sen ulkopuolella. Jo antiikin ajalla kirjoitettua Platon Valtio-dialogia, josta Morekin on saanut vaikutteita, pidetään merkittävänä länsimaisen kirjallisuuden utopiana. Antiikin ja hellenismin ajoilta löytyy muitakin utopiakirjallisuuden esiteoksia. Hesiodoksen Työt ja Päivät kertoo ihmiskunnan moraalista tärveltymistä edeltävästä myyttisestä oikeudenmukaisuuden ajasta. Homeroksen Odysseiassa mainitaan ihmistä ylivertaisempien jumalolentojen kodista Olympos-vuorella. Euhemeroksen kirjoittama tarina Panchaian pyhästä saaresta ja sen suurenmoisesta pääkaupunki Panareasta on kenties varhaisin utopiakirjallisuuden esiteos. Jokaisesta tunnetusta kulttuurista löytyy utopioita joko kirjoitetuksi teksteiksi päätyneinä tai pelkän suullisen tiedon kautta periytyvinä legendoina, myytteinä ja uskomuksina, kuten käsityksinä kuolemanjälkeisestä elämästä. Kristinuskolle pyhässä Raamatussa kuvataan Edenin Puutarha, joka vakiintui länsimaissa paratiisimaisen paikan arkkityypiksi. Yleisesti kuviteltuja onnellisten paikkoja on ollut siitä hetkestä lähtien, kun ihminen on oppinut asettamaan haaveita tulevaisuudelle. (Palmgren 1963, 10-11; Ferguson 1975; Itkonen-Kaila 1998, 10-15; Pinheiro 2006, 151- 152; Sargent 2010, 6-13; Karhu 2016, 28-32.)

1700-luvulta alkanutta ajanjaksoa pidetään utopioiden historiassa merkittävänä. Tuolloin Moren teoksen innoittamana alettiin pohtia ihanneyhteisöjen perustamisen mahdollisuuksia. Osa näistä ihanneyhteisöistä saatettiin käytäntöön jo samalla vuosisadalla, trendin kiihtyessä 1800- ja 1900-luvulla. Utopiayhteisöiksi kutsutuissa pienyhteisökokeiluissa tavoiteltiin valtiojärjestäytyneelle yhteiskuntamuodolle parempaa elämäntapaa, jonka uskottiin piilevän Moren kuvitteellisten saarelaisten elämää muistuttavissa pienyhteisöissä muun muassa kristillisen etiikan ja sosialismin ihanteita noudattaen. (Sargent 2010, 39; Lakkala 2014, 31-33; $57-62)$

Etenkin utopiasosialismi, sosialististen ihanneyhteisöjen konkreettiseen toteuttamiseen pyrkinyt aate, sai aikaan lukuisia utopiakokeiluja ympäri Eurooppaa ja Yhdysvaltoja. Utopiasosialisteista erottautuivat aikansa keskeiset yhteiskuntateoreetikot (Marx, Engels), joiden mukaan todellinen utopia saavutettaisiin ainoastaan poliittisen sosialismin muuttaessa valtio paratiisiksi, jossa omistusoikeuksiin sekä pääoman ja työn väliseen kiistaan liittyvät eettiset ristiriidat olisivat ratkenneet. (Levitas 2010, 41-48; Katajamäki 2016, 46-48; Utopian Studies 2017)

Utopioiden vastakohtakäsitteeksi muodostui dystopia, mikä oli etenkin 1800- ja 1900-luvulla suosioon nousseen kaunokirjallisuuden ansiota. Dystopian tunnetuin märitelmä oli "paha tai huono paikka”. Dystopiakirjallisuuden tyyppipiirteenä pidetään utopiakirjallisuuden ihanneyhteiskuntien kritiikkiä. Keinona tähän on kuvata pieleen mennyt utopia, jonka syyksi tyypillisesti esitetään jokin inhimillinen heikkous (ahneus, vallanhimo), joka tärvelee ihannepaikan irvikuvakseen. Hyviä esimerkkejä dystopiakirjallisuudesta ovat George Orwellin "Vuonna 1984" ja Aldoux Huxleyn "Uljas uusi maailma". (Lahtinen 2002, 169-171; 219_ 220; Sargent 2010, 4; Karhu 2016, 14) Antiutopia on dystopian lähikäsite. Antiutopia kritisoi tiettyä onnellista paikkaa, kuten kaunokirjallisuudessa esitettyä ihanneyhteiskuntaa, tai irvailee yleisesti haaveille moisista paikoista (Claeys \& Sargent 1999, 2). Se on myös parodisempi, toisin kuin vakavaksi varoitukseksi synkästä tulevaisuudesta tarkoitettu dystopia, jossa paikka usein 
kuvataan liioittelevan huonoksi kontrastiksi vertailukohtaan nähden ( $\mathrm{mm}$. Clayes \& Sargent 1999, 2; Baccollini \& Moylan 2003, 4-5; Levitas 2010, 192).

Paitsi dystopiakirjallisuus, varsinkin epäonnistuneet utopiayhteisöt ja sosialismin valtioideologian pimeä puoli diktatuureineen ja väkivaltaisine vallankumouksineen, heikensivät utopioiden uskottavuutta. Tämä on syy siihen, miksi utopia-sanan kuuleminen herättää monissa mielikuvan jostakin mahdottomasta ja siksi epäonnistumaan tuomitusta haaveesta (Gordin, Sargent \& Tilley 2010, 1-2; Levitas 2010, 1-4; Cresswell 2013, 76-84). Eräät tunnetut ajattelijat (mm. Lyotard 1984) ehtivät jopa julistaa utopiat kuolleiksi.

Utopiat ovat saaneet jyrkkää kritiikkiä monilta tunnetuilta tieteen uranuurtajilta, kuten Karl Popperilta (1963) ja Jacob Talmonilta (1957). Talmon (Sargent 2010, 105-106) on todennut, että jokaisen hirvittäviin virheisiin johtaneen suunnitelman taustalla on suuri utooppinen haave. Popper $(1963,359-360)$ puolestaan on kritisoinut utopioita toteutuskelvottomina suunnitelmina, jotka pyrkivät saamaan aikaan liian laajamittaisen muutoksen, joka pakottaa jokaisen hyväksymään sen taustalla piilevä maailmankuva. Utopioiden tunnetuimpia heikkouksia on myös se tosiasia, että jokaisen yksilön uskomukset ihanteellisesta maailmasta poikkeavat toisistaan, jolloin ainakin kaikille yhteisen utopian saavuttaminen on mahdotonta (Kumar 2013, 100).

Utopioita on myös kuvailtu itsessään eräänlaisiksi paradokseiksi, jotka esittävät todelliseen ihmisten väliseen vuorovaikutukseen sisältyvät ristiriidat, erimielisyydet ja jännitteet joko vähäteltyinä tai tyystin sivuutettuina (Mårtensson 1991; Luoto \& Karhu 2018). Utopiaa on myös verrattu tavoitteeseen, joka sisältää niin korkeita päämääriä, että niitä ei tulla milloinkaan saavuttamaan. Tämä on ilmaistu myös vertaamalla utopioita ihanteiden täyttymysten paikoiksi, jotka eivät milloinkaan toteudu (Bastos da Silva 2013, 1-2).

\section{Utopian uusi nousu}

Mielenkiinto utopioita kohtaan on kasvamassa, mikä näkyy viime aikojen kotimaisissa tieteellisissä julkaisuissa. Utopioiden käytännön hyötyihin, kuten niiden kykyyn tarjota vallitseville poliittis-taloudellisille järjestelmille varteen otettavia vaihtoehtoja, on alettu suhtautua vakavammin (Mentula, ym. 2018). Perinteinen utopiakirjallisuuskin on saanut osakseen yhteiskuntamaantieteilijöiden mielenkiintoa (Luoto \& Karhu 2018). Utopia-aiheisiin artikkeleihin törmää säännöllisesti eri tieteenaloilla, maantiede mukaan lukien (mm. Ameel \& Neuvonen 2016; Raunio 2016) ja erityisesti Tulevaisuuden Tutkimusseura on niistä kiinnostunut (Lahtinen 2017; Lakkala 2017). Tärkeä kansainvälinen toimija utopioiden tutkimuksessa on puolestaan poikkitieteellinen tutkijayhteisö Society For Utopian Studies (Utopian Studies 2018). Se on utopioista kiinnostuneiden tieteenharjoittajien yhteinen julkaisu- ja keskustelufoorumi, jossa etsitään uusia tapoja hyödyntää utopioita yhteiskunnan eri osa-alueilla.

Utopia on tieteen monitulkintaisimpia käsitteitä (mm. Levitas 2010, 2-3). Se ei ole kuitenkaan utopioiden tutkimuksen heikkous, vaan pikemminkin se avaa ovet uusille tutkimusmahdollisuuksille. Utopiatutkimuksessa on pyritty viime aikoina lieventämään suhtautumista utopioihin joinain mahdottomina ja siksi toteutumiskelvottomina unelmina (Levitas 2010; Lakkala 2017, 17-20). "Liian hyvää ollakseen totta", on toki yksi utopian merkitysmuodoista. Se voidaan kuitenkin ymmärtää myös tarkoittavan "fiktiossa kuvattua ihanteellista yhteiskuntaa", mutta se voi merkitä myös "mahdollista tulevaisuuden maailmaa" (skenaario). Jotkut saattavat ymmärtää utopian vaatimattomammassa merkityksessään "parempana paikkana tai tilanteena kuin nykyhetkellä vallitsee" (Levitas 2010, 173-178).

Tilanne ja konteksti määrittävät sitä, missä yhteydessä utopiaa terminä kulloinkin viljellään (Levitas 2010, 207). Toki se terminä kytkeytyy miltei aina Moren sille antamiin alkuperäisiin merkityksiin "onnellisena" tai "olemattomana" paikkana (mm. Levitas 2010, 1-6) sekä kysymyksiin mahdollisen ja mahdottoman rajasta (Bloch 1986, 223-240). Nämä merkityssisällöt kuitenkin luovat utopiaan jo niin paljon tulkinallista liikkumavaraa, että yksiselitteistä kaiken kattavaa määritelmää utopialle ei voida saada aikaan.

Utopioiden käytännön hyötyä nykypäivänä onkin pohdittu utopiatutkijoiden keskuudessa. On esitetty, että utopioita voidaan käyttää esimerkiksi luovuuden välineinä yhteiskunnallisia 
suunnitelmia laadittaessa (mm. Levitas 2013). Tämä näkemys puolestaan perustuu erääseen tärkeään utopioita puolustavaan argumenttiin (Fernando ym. 2017, 2-5; Lakkala 2017, 19-20). Sen mukaan utopioita ei ole tarkoitettu toteutettaviksi sellaisinaan, vaan niiden tarkoitus on herättää keskustelua mm. kritisoimalla vallitsevan yhteiskunnan heikkouksia ja saada siten aikaan muutos parempaan suuntaan. Utopiaan voidaankin suhtautua välineenä, joka innostaa tekemään kaivattu muutos, joka ei johda täydelliseen lopputulokseen, mutta kehittää maailmaa vähän paremmaksi paikaksi. Darko Suvin (1997, 127) suhtautuu utopioihin juuri tässä merkityksessä: ajatuskokeina - ei päämäärinä - kuvitella vaihtoehtoisia todellisuuksia.

\section{Utopismi - utopioiden alkuvoima}

Ihmisessä ajatellaan piilevän muuttumaton perusluonteenpiirre, joka saa hänet haaveilemaan paremmasta maailmasta tai vaatimattomammin paremmasta henkilökohtaisesta elämästä ( $\mathrm{mm}$. Marcuse 1955; Bloch 1985; Sargent 1994, 3). Vaihtoehtoisesti tätä inhimillistä paremman maailman kaipuuta on nimitetty "utooppiseksi impulssiksi" (Geogheghan 1987, 2). Sitä vastoin utopismi, toinen utopiatutkimuksen käsite, on utopiaakin monisisältöisempi termi, jolle ei niin ikään löydy yksiselitteistä määritelmää.

Utopismia on määritelty muun muassa seuraavilla tavoilla (Sargent 2010, 5). Se merkitsee ihmisen kykyä unelmoida paremmasta maailmasta sisältäen paitsi lukuisia ideoita, uskomuksia ja arvoja, joiden avulla se uskotaan saavutettavan sekä mukaan lukien pelkoja ja uhkia, jotka ovat näiden unelmien toteuttamisen tiellä. Utopismin vaatimattomampi määrite on "yhteiskunnallinen unelmoiminen" (Claeys \& Sargent 1999, 1). Ruth Levitas (2010, 209) on määritellyt utopismin "ihmisen intohimoksi kehittyä paremmaksi olennoksi", josta seuraa parantunut maailma.

Seuraava vertaus valaisee utopian ja utopismin välistä terminologista eroa. Jos utopiaan suhtautuu kuvitteellisena onnellisten ihmisten paikkana, niin utopismi on se ihmisen perusluonteen piirre, joka inspiroi kuvitelmia kyseisistä paikoista. Utopismi edeltää utopiaa, sillä sitä ilman utopioita ei ole (Pinheiro 2006, 148). Utopismi sisältää kaiken sen, mikä saa mielikuvituksen tuottamaan paremman paikan kuvitelmia, mutta se viittaa myös kokonaiseen ajattelutapaan ja sen mukaiseen asennoitumiseen, joiden uskotaan kehittävän ihmisestä parempi olento (Kolawski 1983; Sargent 2010, 5). Yksinkertaisimmillaan utopismi tarkoittaa ihmisen halua tyydyttää koetut puutteet, kuten ravita nälkäistä vatsaa tai pukeutua vilustumisen välttämiseksi (Sargent 2010, 102). Näitä tarpeiden tyydytystapoja voidaan myös aina kehittää paremmiksi, mikä on myös utopismia yksinkertaisimmillaan.

Kuuluisa utopismin teoreettisen sisällön analysoijia, Ernst Bloch, tunnetaan utopismin puolestapuhujana. Hän korostaa haveilun ja toivomisen merkitystä siinä prosessissa, joka saa ihmisen siirtämään ajatuksensa teoiksi. (Bloch 1986, 45-46) Blochin mukaan on sekä luonnollisia että keksittyjä tarpeita, joita ihmisellä on halu tai himo tyydyttää. Se puolestaan johtaa toiveeseen tilanteesta, jossa tuo tarve on tyydytetty. Kaikki toivominen ei johda toiveen toteuttamiseen, mutta ilman sitäkin toivominen on ihmiselle hyödyllistä. Blochin mukaan se on edellytys sille, että ihminen ylipäätänsä pystyy ajattelemaan nykytilan paremmaksi, mikä voi johtaa intohimoiseen tahtoon muuttaa sitä paremmaksi.

Utopismia on kritisoitu toteamalla, että se sama sisäinen voima, joka saa ihmisen tavoittelemaan parempaa maailmaa tekee itse asiassa paremman maailman tavoittamisen mahdottomaksi, muiden toimiessa samoin (Levitas 2010; Sargent 2010). Karl Popper pitää utopismia vaarallisena voimana, joka on itsetuhoinen ja väkivaltaan johtava (Widdicombe ym. 2017, 3). Myös Bloch (1985, 23-24) on tietoinen utopismin ongelmasta: yhden tarpeen tyydyttäminen johtaa uuteen tarpeeseen ja niin edelleen. Utopismi on saanut vastakohtakäsitteekseen antiutopismin, jolla nimenomaan tarkoitetaan utopismiin sisältyvien heikkouksien ja vaarojen paljastamista (Bastos da Silva 2013, 1; Vieira 2013, 5).

Bloch on tehnyt selkoa utopismin yhteydestä mahdollisen ja mahdottoman käsitteisiin. Hänen mukaan ihmisen toimintaa säätelevät kunakin hetkenä tietyt tosiasiat, kuten luonnonlait, jotka on pakko ottaa huomioon. Sen sijaan "yhteiskunnalliset lainalaisuudet" eivät ole Blochille samanlaisia "välttämättömiä tosiasioita", vaan niihin nimenomaan kytkeytyy mahdollisuus muutokseen. Bloch korostaa, että on olemassa teoreettisia ja reaalisia mahdollisuuksia, joista 
jälkimmäiset koskevat uusia ajattelutapoja, joilla yhteiskuntaa voidaan muuttaa erilaiseksi rikkomatta luonnonlakeja. Utopismi on konkreettisimmillaan näiden todellisuudessa vallitsevien reaalisten mahdollisuuksien ilmaisemista. (Bloch 1986, 223-237; Levy 1997, 177-183)

\section{Utopia maantieteen teorioissa}

Maantiede on tilan ja paikan tutkimusta. Antiikin filosofit, etenkin Platon ja Aristoteles, valoivat tilan ja paikan ajattelulle ja siten varhaiselle maantieteelle teoreettisen pohjan. Molemmat filosofit kirjoittivat runsaasti paikasta, topoksesta, tilasta eli khorasta sekä tyhjyyttä tai päättymättömyyttä merkitsevästä kenonista. Sekä khora että topos viittaavat kenonista eroten johonkin olevaan ja muutoskykyiseen - eivät tyhjään tai olemattomaan. (Cresswell 2013: 19-21; Casey 1997: 4-5, 32-35)

Khoraa ja toposta käytetään nykyaikaisissa paikkateorioissa toisiinsa yhteen kietoutuneina siten, että paikan (topos) uskotaan aina olevan hitaassa tai nopeassa muutostilassa tullen koko ajan joksikin, mitä se ei vielä aikaisemmin ollut. (Pred 1984; Kymäläinen 2006, 206-212) Utopian voidaan ajatella liittyvän tilan ja paikan suhteeseen seuraavasti. Se mitä paikka ei ole, mutta jota se tavoittelee ehkä koskaan saavuttamatta, ohjaa merkittävästi sitä muutosprosessia, jossa paikka jatkuvasti on. Utopia - jokin paikan tulevaisuuden tavoitetila - siis määrittää paikan olemusta.

Utopiat liittyvät myös paikkatutkijoiden pohtimaan tyhjän tilan (empty space) problematiikkaan (mm. Casey 1997, 80; Heidegger 1998, 86-93; Malpas 2012). Tyhjä tila on ehto kaikelle sille, mitä olevaksi (ei-tyhjäksi) kutsutaan. Ihminen on toisinaan taipuvainen kiinnittämään liikaa huomiota kaikkeen näkyvään ja käsin kosketeltavaan kuin näkymättömään ja aineettomaan (mm. Tuan 1977, 161-165). Tällöin hän usein unohtaa tyhjän tilan merkityksen ja etenkin sen, että kaikki hänen näkemänsä - aineellinen ja konkreettinen - on joskus ollut "tyhjyyttä" siinä mielessä, ettei sitä aina ole ollut. Tyhjä tila on eräänlainen utopia. Se on alusta, jossa on potentiaalia toistaiseksi toteutumattomille paikoille.

1970-luvun humanistiset maantieteilijät (Ley 1974; Tuan 1976; Seamon 1979) etsivät paikan tulkintaan uusia näkökulmia tuomalla paikan ajatteluun filosofisia piirteitä tarkoituksena löytää ihmisen subjektiivisesta kokemusmaailmasta, kuten tunteista ja arvoista, paikan kokemista värittäviä tekijöitä (Tuan 2004, 17-24; Kymäläinen 2006, 205-211; Cresswell 2013, 102-109). Tuolloin muotoiltiin myös paikattomuuden teoreettinen käsite, jolla tarkoitettiin alun perin paikkaa, jotka eivät tunnu miltään ja joissa olo koetaan tyhjäksi (Relph 1976, 43-44).

Michel Foucault (1984, 3-4; 1986: 22-27; Casey 1997, 300) kirjoitti utopioista ja heterotopioista. Utopian hän määritteli paikattomaksi paikaksi tai "epäpaikaksi". Epäpaikat antavat itsestään tulkitsijalleen täydellisen mielikuvan ja täydellisyytensä vuoksi erottuvat edukseen. Niitä ei kuitenkaan ole varsinaisesti olemassa ainakaan siinä merkityksessä, että niiden fyysinen sijainti voitaisiin paikantaa jonnekin. Heterotopian Foucault puolestaan erotti utopiasta siten, että sille on mahdollista paikantaa todellinen "oleva" sijainti esimerkiksi kartalla.

Marxilaisen koulukunnan David Harvey (2000, 31-32) on tunnetuimpia utopioista maantieteellisessä yhteydessä kirjoittaneista tutkijoista. Hänet tunnetaan "toivon maantieteen" (spaces of hope) käsitteestä, jota myös suomalaiset maantieteilijät ovat lainanneet ( $\mathrm{mm}$. Katajamäki 2016, 35). Toivon maantieteellä Harvey tarkoittaa vaihtoehtoisia ajattelutapoja, jotka vastustavat pääomavaltaisen talouden luomaa tilallista todellisuutta, joka syntyy taloudellisen voiton maksimoinnin keskiöön asettamisesta. Näitä vaihtoehtoisia tapoja Harvey kutsuu myös utopioiksi (spaces of utopia), koska ne vastustavat vallalla olevaa maailmanmenoa. Ilman näitä vaihtoehtoja Harvey (1996) pelkää päädyttävän karuun taloudellisen laskelmoinnin maailmaan, jossa inhimillisyys on toissijaisessa asemassa.

Darko Suvin, kirjallisuudentutkija ja filosofi, on analysoinut utopioita maantieteilijää kiinnostavalla tavalla. Hän $(1997,130-134)$ luonnehtii utopioita imaginaarisiksi tiloiksi, joissa arvo on ensisijaisessa asemassa etäisyyteen nähden. Suvinin mukaan tuossa imaginaarisessa tilassa on toimijoita, jotka operoivat tietyssä paikassa (locus) ja suuntautuvat jotain toiminnan päämäärää, horisonttia, kohden. Suvinin mukaan horisontin ja locuksen suhde määrittävät utopian luonnetta keskeisesti. Jos lokus dominoi horisonttia, utopia on staattinen, joka ei 
anna sijaa muutokselle. Utopiakirjallisuuden teos saattaa esittää kuvitteellisen paikan, joka on tilana järjestynyt palvelemaan tiettyjä rikkomattomia periaatteita, joita ei muuteta edes tilanteen vaatiessa toisin.

\section{Utopian, utopismin ja paikan yhteyden soveltaminen aluekehittämiseen}

Keskeisen haaste ajatella alue utopioina paikan käsitteen kautta on siinä, että paikkaan voidaan suhtautua maantieteelliseltä laajuudeltaan suurellakin vaihtelulla. Paikka voi tarkoittaa mitä tahansa yksittäisen rakennuksen huoneesta aina kokonaisiin kuntiin, maakuntiin ja valtioihin asti, edellisten kolmen kohdalla siirryttäessä käyttämään termiä alue. Utopioiden ja utopismin teoreettinen yhteys paikkaan pätee pääasiassa myös silloin, kun käytetään alueellista tarkastelutasoa, kunhan huomioidaan sen tuomat haasteet. Millä tavalla utooppisuus vaihtelee esimerkiksi sen mukaan, tutkitaanko yksittäistä alueella toimivaa organisaatiota, kuten yritystä, vai kunnan kaltaista aluetta kokonaisuutena?

Utopian monitulkintaisuus, tilannesidonnaisuus ja arvoituksellisuus innostavat pohtimaan millaisia käyttökelpoisia työkaluja utopiat voivat olla aluekehittämisessä (vrt. Mentula ym. 2018), johon suhtaudutaan yhä monitasoisempana ja siksi toisinaan vaikeasti hahmotettavana ympäristönä, jossa toistensa kanssa vuorovaikuttavat toimijat omaavat sekä yhteisiä että toisistaan poikkeavia päämääriä. Maakuntien, kuntien ja kylien sekä niiden asukkaiden, jotka lopulta muodostavat erilaisiin ryhmiin ja organisaatioihin sitoutuneina nämä edeltävät aluetasot, toimivat henkilökohtaisten ja toisaalta kollektiivisten parempaan elämään tähtäävien haaveiden eteenpäin ajamina, jotka nivoutuvat yhdessä alueiden kasvua ja elinvoimaa edistäväksi voimaksi. Jos utopismi on ihmisessä piilevä perusvoima, niin miten se muotoutuu varsinaiseksi alueiden toimijoita ohjaavaksi utopiaksi? Entä ovatko nämä utopiat aluekehittämisen välineinä lopulta yhtä kuin suuria lupauksia, jotka ilmenevät sanoina, tekoina tai molempina vai jotain muutakin?

Utopioiden suhteen pohtiminen nykyaikaiseen aluekehittämiseen johtaa myös erääseen perustavaan kysymykseen. Miten utopia ylipäätänsä voidaan ymmärtää tämän päivän aluekehittämisessä, joka on edellä kuvattu sekalainen seurakunta intresseiltään poikkeavia yksilöitä ja ryhmiä, jotka muodostavat alueen yhdessä sellaisten tekijöiden, kuten historian, kulttuurin ja teknologian rinnalla? Koko utopian käsite saatetaan joutua ajattelemaan uudelleen tiedostaessamme, että ihmistä perustavan laatuisesti motivoivana luontaisena piirteenä olemme kaikki eräänlaisia utopisteja, mikä pätee myös aluekehittämisen toimijoihin ja sitä kautta koko aluekehittämisen luonteeseen.

\section{Lähteet}

Ameel, L. \& Neuvonen, A. (2016) Utopian jälkeen: vaihtoehtoisia tulevaisuusvisioita kirjallisuudessa ja kaupunkistrategioissa. Terra 128(4) 215-220.

Baccolini, R. \& Moylan T. (2003) Dark Horizons: Science Fiction and Dystopian Imagination. Routledge, New York \& London.

Bastos da Silva, J. (2013) Introduction: revisiting the rationales of utopianism. In Bastos da Silva, J. (ed.) The Epistemology of Utopia: rhetoric, theory and imagination, 1-6. Cambridge Scholars Publishing, Cambridge.

Bloch, E. (1986) The Principle of Hope. Editors N. Plaice, S. Plaice \& P. Knight. MITT Press, Cambridge.

Bloch, E. (1985) Ennakoitu todellisuus: mitä on utooppinen ajattelu ja mitä se saa aikaan. Teoksessa Rahkonen K. \& Sironen, E. (toim.) Ernst Bloch: Utopia, luonto, uskonto, 22-33. Kansan Sivistystyön Liitto, Helsinki.

Casey, E. (1997) The Fate of Place: A Philosophical history. University Of California Press, Oakland.

Claeys, G. \& Lyman S. (1999) Utopia Reader. New York University Press, New York.

Cresswell, T. (2013) Geographic Thought: A Critical introduction. Wiley-Blackwell, London.

Ferguson, J. (1975). Utopias of the Classical World. Cornell University Press, New York.

Fernando, J., Burden, N. \& Ferguson, A. (2016) Functions of Utopia: how utopian thinking motivates societal engagement. Personal and Societal Psychology Bulletin 44(5) 779-792.

Foucault, M. (1986) Of Other Spaces. Diacritics 16(1) 22-27.

Foucault, M. (1984) Of Other Spaces: Utopias and Heterotopias. Architecture / Mouvement / Continuité. Saatavissa 18.3.2019: http://web.mit.edu/allanmc/www/foucault1.pdf.

Geogheghan, V. (1987) Utopianism and Marxism. Peter Lang, New York.

Gordin, P., Sargent, L. \& Tilley, H. (2010) Utopia and Dystopia beyond space and time. In Utopia/Dystopia: Conditions of Historical Possibility, 1-17. Princeton University Press, New Jersey. 
Harvey, D. (1996) Justice, nature and the geography of difference. Blackwell, Oxford.

Harvey, D. (2000) Spaces of Hope. University of California Press, Berkeley.

Heidegger, M. (1998). Patmarks. Editor W. McNeill. Cambridge University Press, Cambridge \& New York.

Itkonen-Kaila, M. (1998) Thomas More ja hänen utopiansa. Teoksessa Itkonen-Kaila M. (toim.) Utopia: Thomas More, 7-21. WSOY, Juva.

Karhu, M. (2016) Utopia- ja dystopiakirjallisunden klassikkoteokset paikekateoreettisessa tarkastelussa: T. Moren Utopia, A. Huxleyn Uljas uusi maailma ja G. Orwellin Vuonna 1984. Vaasan yliopisto, Vaasa.

Katajamäki, H. (2016) Paikan poika: Merkintöjä uran varrelta. Julkaisupaikka ja kustantaja tuntematon.

Kolawski, L.(1983) Death of Utopia Reconsidered. In Sterling M. \& Mcmurrin M. (eds.) The Tanner Lectures of Human Value, Vol 4. University of Utah Press, Salt Lake City.

Kumar, K. (2013) The Future of Utopia. In Bastos da Silva J. (ed.) Epistemology of Utopia: Rhetoric, Theory an Imagination, 93-115. Cambridge Scholars Publishing, Newcastle.

Kymäläinen, P. (2006) Paikan ajattelun haasteita. Teoksessa Knuuttila S., Laaksonen S. \& Piela U. (toim.) Paikeka: Eletty, koettu, kuviteltu, kerrottu, 203-217. Gummerus, Jyväskylä.

Lahtinen, M. (2002) Matkoja Utopiaan. Otavan Kirjapaino: Keuruu.

Lahtinen, M. (2017) Utopiat ja niiden vastakohdat. Futura (1) 3-13.

Lakkala, K. (2017) Utopiat yhteiskunnallisen mielikuvituksen metodologiana. Futura (1) 14-21.

Lakkala, K. (2014) Utopia tänään: ybteiskunnallisen mielikuvituksen metodologiaa. Kampus Kustannus, Jyväskylä.

Levitas, R. (2010) The Concept of Utopia. Peter Lang, New York.

Levitas, R. (2013) Utopia as Method: The Imaginary Reconstitution of Society: The imaginary reconstruction of society. Palgrave Mcmillan, UK.

Levy, Z. (1997) Utopia and Reality in the philosophy of Ernst Bloch. In Daniel, J. \& Moylan, T. (eds.) Not Yet: Reconsidering Ernst Bloch. Verso, London \& New York.

Ley, D. (1974) The Black. Inner City as Frontier Outpost: Images and Behavior of a Philadelphia neighborhood. Association of American Geographers, Washington.

Lundström, N. (2015). Aluekehittämisen pirullinen peli. Saatavissa 18.3.2019: https://www.univaasa.fi/materiaali/pdf/ isbn_978-952-476-623-4.pdf.

Luoto, I. \& Mikko K. (2018) Utopiakirjallisuns ja aluekehittämisen paradoksit. [Painossa].

Lyotard, J. F. (1984) The Postmodern condition: A Report on knowledge. University of Minnesota Press, Minneapolis.

Malpas, J. (2012). Heidegger and the thinking of place: Explorations in the topology of being. The MIT Press, Cambridge \& London.

Marcuse, H. (1955) Eros and Civilization: Philosophical inquiry into Freud. Beacon Press, Boston.

Mentula, M., Lakkala K., Suominen S., Era H. (2018). Utopia työkaluna: Irti vaihtoehdottomunden valheesta. Painotalo Trinket, Helsinki.

Mårtensson, B. (1991) The Paradoxes of Utopia: Study in Utopian Rationalism. Philosophy of The Social Sciences 21(4) 476-514.

Palmgren, R. (1963) Pelon ja toivon utopiat. Sanan Tie, Tampere.

Pinheiro, M. (2006) Utopia and Utopias: A Study on a Literary Genre in Antiquity. In Authors, Authority and Interpreters In The Ancient Novels, 147-171. Saatavissa 14.9.2018: https://rih.ub.rug.nl/AN/article/view/24410/21860.

Popper, K. (1963) The Poverty of Historicism. Routledge \& Kegan Paul, London.

Pred, A. (1984) Place as historically contingent preocess: Structuration and the time-geography of becoming places. Association of American Geographers 74, 279-297.

Raunio, M. (2006) Monikulttuurinen kaupunki: rasistinen dystopia vai kosmopoliittinen utopia? Terra 118(2), 132-133.

Relph, E. (1976) Place and placelessness. Pion, London.

Sargent, L. (1994). The three faces of utopianism revisited. Utopian Studies 5(1) 1-37.

Sargent, L. (2010) Utopianism: a very short introduction. Oxford University Press, New York.

Seamon, D. (1979) Geography of the lifeworld: Movement, rest and encounter. St. Martin, New York.

Suvin, D. (1997) Locus, Horizon and Orientation: The Concept of possible worlds as a key to utopian studies. Teoksessa Daniel, J. \& Moylan, T. (eds.) Not Yet: Reconsidering Ernst Bloch, 122-137. Verso, London \& New York.

Talmon, J. (1957) Utopianism and Politics. Conservative Political Centre, London.

Tuan, Y. F. (1976) Humanistic geography. Annals of the Association of American Geographers 66(2) 266-276.

Tuan, Y. F. (2004) Paikan taju: aika, paikka ja minuus. Teoksessa Knuuttila S., Laaksonen S. \& Piela U. (toim.) Paikea: Eletty, koettu, kuviteltu, kerrottu, 15-30. Gummerus, Jyväskylä.

Tuan, Y. F. (1977) Space and Place: The Perspective of experience. University of Minnesota Press, Minneapolis.

Utopian Studies (2017) The Development of Utopian Socialism. 13.9.2018: <https://www.marxists.org/subject/ utopian/index.htm>

Utopian Studies (2018) The Society For Utopian Studies. 13.9.2018< <ttps://utopian-studies.org/>

Vieira, F. (2013) Dystopian matters: on the Page, on Screen, on Stage. Cambridge Scholars Publishing, Newcastle.

Viinamäki, O-P \& Salminen, A. (2008) Aluehallintojen mosaiilkki. Kansainvälisiä vertailevia buomioita aluehallintojen nykytilasta ja undistuksista. Hallinnon kehittäminen 8. Valtionvarainministeriön julkaisuja. Valtiovarainministeriö, Helsinki.

Widdicombe, T., Morris J. \& Kross A. (2017) Historical Dictionary of Utopianism. Rowman \& Littlefield, New York \& London. 